\title{
Line $\times$ Tester Mating Design Analysis for Grain Yield and Yield Related Traits in Bread Wheat (Triticum aestivum L.)
}

\author{
Zine El Abidine Fellahi, ${ }^{1}$ Abderrahmane Hannachi, ${ }^{1}$ \\ Hamenna Bouzerzour, ${ }^{2}$ and Ammar Boutekrabt ${ }^{3}$ \\ ${ }^{1}$ National Institute of Agricultural Research, Setif Agricultural Research Unit, Setif 19000, Algeria \\ ${ }^{2}$ Faculty of Life and Natural Sciences, Ecology and Plant Biology Department, University of Ferhat Abbas, Setif 1 19000, Algeria \\ ${ }^{3}$ Faculty of Agro-Veterinary and Biological Sciences, Agronomy Department, University of Saad Dahlab, Blida 09000, Algeria
}

Correspondence should be addressed to Zine El Abidine Fellahi; zinou.agro@gmail.com

Received 6 March 2013; Revised 20 May 2013; Accepted 29 May 2013

Academic Editor: David Clay

Copyright (C) 2013 Zine El Abidine Fellahi et al. This is an open access article distributed under the Creative Commons Attribution License, which permits unrestricted use, distribution, and reproduction in any medium, provided the original work is properly cited.

\begin{abstract}
Nine bread wheat (Triticum aestivum L.) genotypes were crossed in a line $\times$ tester mating design. The $20 \mathrm{~F}_{1}$ 's and their parents were evaluated in a randomized complete block design with three replications at the Field Crop Institute-Agricultural Experimental Station of Setif (Algeria) during the 2011/2012 cropping season. The results indicated that sufficient genetic variability was observed for all characters studied. $\mathrm{A}_{899} \times$ Rmada, $\mathrm{A}_{899} \times$ Wifak, and $\mathrm{A}_{1135} \times$ Wifak hybrids had greater grain yield mean than the parents. $\mathrm{A}_{901}$ line and the tester Wifak were good combiners for the number of grains per spike. MD is a good combiner for 1000-kernel weight and number of fertile tillers. $\mathrm{HD}_{1220}$ is a good general combiner to reduce plant height; Rmada is a good general combiner to shorten the duration of the vegetative growth period. $A_{901} \times$ Wifak is a best specific combiner to reduce plant height, to increase 1000-kernel weight and number of grains per spike. AA $\times$ MD is a best specific combiner to reduce duration of the vegetative period, plant height and to increase the number of kernels per spike. $A_{899} \times$ Wifak showed the highest heterosis for grain yield, accompanied with positive heterosis for the number of fertile tillers and spike length, and negative heterosis for 1000-kernel weight and the number of days to heading. $\sigma_{\mathrm{gca}}^{2} / \sigma_{\mathrm{sca}}^{2},\left(\sigma_{D}^{2} / \sigma_{A}^{2}\right)^{1 / 2}$ low ratios and low to intermediate estimates of $h_{\mathrm{ns}}^{2}$ supported the involvement of both additive and nonadditive gene effects. The preponderance of non-additive type of gene actions clearly indicated that selection of superior plants should be postponed to later generation.
\end{abstract}

\section{Introduction}

Bread wheat (Triticum aestivum L.) is an important staple food in Algeria. This crop ranks third after durum wheat (Triticum durum Desf.) and barley (Hordeum vulgare L.), with a yearly cropped area of 0.8 million hectares, representing $24.2 \%$ of the 3.3 million hectares devoted to small grain cereals. Algeria imported 3.0 million tons of bread wheat in $2010 / 2011$, to remedy the decline in the domestic production and to build stocks to meet the needs.

Increasing wheat production can be achieved by application of improved agronomic technics, developing and adopting high yielding varieties. Major emphasis, in breeding program, is put on the development of improved varieties with superior qualitative and quantitative traits and resilience to abiotic stresses. In fact, genetic improvement in bread wheat, having better tolerance against terminal heat and water stress, has a good promise to improve grain yield average and total wheat production.

However to breed high yielding varieties, breeders often face the problem of selecting parents and crosses. In this context various breeding approaches have been suggested. The line $\times$ tester analysis method introduced by Kempthorne [1] is one of the powerful tools available to estimate the combining ability effects and aids in selecting desirable parents and crosses for exploitation in pedigree breeding [2-4]. Performances per se do not necessarily reveal which parents are good or poor combiners. To surmount this difficulty, it is necessary to gather information on the nature of gene actions. General combining ability is attributed to additive type of 
gene effects, while specific combining ability is attributed to nonadditive type of gene actions. Nonadditive gene type of actions is not reliably fixable whereas additive type of gene actions or complementary type epistatic gene interactions are reliably fixable [5-7].

Heterosis estimates, for different morphological and yield related characters, are attributed to both additive and nonadditive gene actions. Heritability gives information about genetic variation; it is useful for predicting the response to selection in the succeeding generations. Heritability is dependent upon the nature of gene action [8-10]. Better understanding of the underlying genetic control of important traits in bread wheat is useful in breeding for higher grain yield. Kamaluddin et al. [11] reported high contribution of general combining ability for genetic control of bread wheat characters. Kumar and Maloo [12] identified the best specific and general combiners that were efficient for breeding days to flowering and grain yield in bread wheat. Involvement of both additive and dominance gene actions was also reported for genetic control of heading time in wheat [7], grain yield [13], number of grains per spike, 1000-kernel weight [14], and fertile tillers per plant [15]. Ahmad et al. [16] reported that additive gene effect was important for days to heading. Khan and Habib [17] observed that grain weight was controlled by over dominance type of gene action.

The objectives of this study are to assess the combining ability, to determine the nature and magnitude of gene actions and to estimate heterosis and heritability for yield and yieldrelated traits in a line $\times$ tester mating design in bread wheat.

\section{Materials and Methods}

The present investigation was carried out at the Field Crop Institute-Agricultural Experimental Station of Setif (ITGCAES, $36^{\circ} 12^{\prime} \mathrm{N}$ and $05^{\circ} 24^{\prime} \mathrm{E}$, Algeria) during the 2010/2011 and 2011/2012 cropping seasons. The soil of the experimental site is silty clay, with $\mathrm{CaCO}_{3}$ and organic matter contents of $35 \%$ and $1.35 \%$, respectively. The experimental material comprises nine bread wheat (Triticum aestivum L.) genotypes. Five genotypes, Acsad 901 $_{10}, \operatorname{Acsad}_{899}, \operatorname{Acsad}_{1135}, \operatorname{Acsad}_{1069}$, and Ain Abid, were used as females, hereafter designated as lines; and four genotypes: Mahon Demias, Rmada, $\mathrm{HD}_{1220}$, Wifak, designated as testers, were used as males. Mahon Demias is a genealogical selection from a land race introduced from Balearic Islands in the mid-forties of the past century. This cultivar is widely adapted to the arid and semiarid high plateaus of Algeria. $\mathrm{HD}_{1220}$ is a selection from CIMMYT segregating material; it was released as cultivar in the nineties. Drought tolerant and early maturing, this variety gained large acceptance from farmers due to its high yielding potential [18].

The nine parents were crossed to produce $20 \mathrm{~F}_{1}$ hybrids according to the line $\times$ tester mating design developed by Kempthorne [1]. $F_{1}$ seeds were sown in the field, along with their parents, in a randomized complete block design with three replications. Each plot comprised one row of $2.5 \mathrm{~m}$ length with space of $30 \mathrm{~cm}$ between rows and seeds were placed $15 \mathrm{~cm}$ apart. Recommended cultural practices were followed to raise a good crop. Monoammonium phosphate
TABLE 1: ANOVA for line $\times$ tester analysis.

\begin{tabular}{lcc}
\hline Source of variation & Degree of freedom $(\mathrm{df})$ & Mean square \\
\hline Replication $(r)$ & $(r-1)$ & \\
Genotypes $(g)$ & $(g-1)$ & $\mathrm{MS}_{2}$ \\
Parents $(p)$ & $(p-1)$ & \\
Parents versus crosses & 1 & \\
Crosses $(c)$ & $(c-1)$ & $M_{l}$ \\
Lines $(l)$ & $(t-1)$ & $M_{t}$ \\
Testers $(t)$ & $(l-1)(t-1)$ & $M_{l \times t}$ \\
Lines $\times$ testers & $(r-1)(t-1)$ & $\mathrm{MS}_{1}$ \\
Error &
\end{tabular}

Where $\mathrm{MS}_{2}, M_{l}, M_{t}, M_{l \times t}$, and $\mathrm{MS}_{1}$ were genotypic mean square, line mean square, tester mean square, line $\times$ tester mean square, and error mean square, respectively.

$\left(52 \% \mathrm{P}_{2} \mathrm{O}_{5}+12 \% \mathrm{~N}\right)$ with $80 \mathrm{~kg} \mathrm{ha}^{-1}$ was applied just before sowing and $75 \mathrm{~kg} \mathrm{ha}^{-1}$ of Sulfate $\left(26 \% \mathrm{~N}+35 \% \mathrm{SO}_{3}\right)$ was spread at tillering stage. Weeds were controlled by application of $12 \mathrm{~g} \mathrm{ha}^{-1}$ of Granstar [Methyl Triberunon] herbicide mixed with water.

Five competitive plants (excluding border plants) were tagged before heading and data were recorded for the number of days to heading, plant height, spike length, number of fertile tillers per plant, number of grains per spike, 1000kernel weight, and grain yield per plant. Data recorded were subjected to analysis of variance according to Steel and Torrie [19] to determine significant differences among genotypes. Combining ability effects are very effective genetic parameters in deciding the next phase of breeding programs. They were computed according to the line $\times$ tester method [20]. Line $\times$ tester analysis was performed as outlined in the format of ANOVA table given in Table 1.

The variances for general and specific combining ability were tested against their respective error variances, derived from the analysis of variance of the different traits as follows:

Covariance of half-sib of line

$$
\begin{aligned}
& =\text { Cov.H.S. (line) } \\
& =\frac{M_{l}-M_{l \times t}}{r t},
\end{aligned}
$$

Covariance of half-sib of tester

$$
\begin{aligned}
& =\text { Cov.H.S. (tester) } \\
& =\frac{M_{t}-M_{l \times t}}{r l},
\end{aligned}
$$

Covariance of full sib

$$
\begin{aligned}
= & \text { Cov.F.S. } \\
= & \frac{\left(M_{l}-M_{e}\right)+\left(M_{t}-M_{e}\right)+\left(M_{l \times t}-M_{e}\right)}{3 r} \\
& +\frac{6 r \text { Cov.H.S. }-r(l+t) \text { Cov.H.S. }}{3 r} .
\end{aligned}
$$


TABLE 2: Analysis of variance for combining ability effects of different bread wheat characters.

\begin{tabular}{|c|c|c|c|c|c|c|c|c|}
\hline Source & $\mathrm{df}$ & DHE & PHT & SL & FT & TKW & NG & GY \\
\hline Rep & 2 & 5.7 & 54.1 & 0.3 & 13 & 12 & 52.3 & 62 \\
\hline Gen & 28 & $15.6^{*}$ & $226.8^{*}$ & $2.9^{*}$ & $23.4^{*}$ & $33.2^{* *}$ & $152.8^{* *}$ & $39.7^{*}$ \\
\hline $\operatorname{Par}(\mathrm{P})$ & 8 & $26.4^{*}$ & $348.0^{*}$ & $2.6^{*}$ & $29.9^{*}$ & $63.1^{* *}$ & $279.1^{* *}$ & $42.7^{*}$ \\
\hline Crosses (C) & 19 & $10.7^{*}$ & $171.8^{*}$ & $2.5^{*}$ & $19.6^{*}$ & $22.3^{* *}$ & $107.6^{* *}$ & $33.8^{*}$ \\
\hline$P$ versus $C$ & 1 & $21.4^{*}$ & $301.4^{*}$ & $11.9^{*}$ & $44.5^{*}$ & $0.9^{\text {ns }}$ & $2.3^{\text {ns }}$ & $129.0^{*}$ \\
\hline Lines (L) & 4 & $21.2^{*}$ & $89.0^{*}$ & $3.3^{*}$ & $28.1^{*}$ & $26.8^{* *}$ & $120.5^{*}$ & $65.5^{*}$ \\
\hline Testers (L) & 3 & $39.5^{*}$ & $751.2^{*}$ & $2.5^{*}$ & $37.2^{*}$ & $91.1^{* *}$ & $357.7^{* *}$ & $25.8^{*}$ \\
\hline $\mathrm{L}$ versus T & 1 & $7.6^{\mathrm{ns}}$ & $174.7^{*}$ & $0.3^{\mathrm{ns}}$ & $15.1^{*}$ & $45.3^{*}$ & $267.6^{*}$ & $2.2^{\mathrm{ns}}$ \\
\hline $\mathrm{L} \times \mathrm{T}$ & 12 & $4.2^{\mathrm{ns}}$ & $46.8^{*}$ & $1.9^{*}$ & $10.0^{*}$ & $3.6^{\mathrm{ns}}$ & $40.8^{*}$ & $25.6^{*}$ \\
\hline Error & 56 & 2.5 & 24.1 & 0.7 & 3.4 & 6 & 11.1 & 6.5 \\
\hline
\end{tabular}

DHE: number of days to heading, PHT: plant height $(\mathrm{cm})$, SL: spike length $(\mathrm{cm})$, FT: number of fertile tillers, TKW: thousand-kernel weight (g), NG: number of grains per spike, GY: grain yield $(\mathrm{g}), \mathrm{ns}, *$ and $* *$ : non-significant and significant effect at 0.05 and 0.01 probability, P: parents, C: crosses, L: lines, and T: testers.

While Cov. H.S. (average) was calculated by the formula

$$
\begin{aligned}
& \text { Cov.H.S. (average) } \\
& \qquad=\frac{1}{r(2 l t-l-t)}\left[\frac{(l-1)\left(M_{l}\right)+(t-1)\left(M_{t}\right)}{l+t-2}-M_{l \times t}\right] .
\end{aligned}
$$

Assuming no epistasis, variance due to GCA $\left(\sigma_{\mathrm{gca}}^{2}\right)$ and variance due to SCA $\left(\sigma_{\mathrm{sca}}^{2}\right)$ were calculated as follows:

$$
\begin{gathered}
\sigma_{\mathrm{gca}}^{2}=\text { Cov.H.S. }=\left(\frac{1+F}{4}\right) \sigma_{A}^{2} \\
\sigma_{\mathrm{sca}}^{2}=\left(\frac{1+F}{2}\right)^{2} \sigma_{D}^{2} .
\end{gathered}
$$

Additive and dominance genetic variances $\left(\sigma_{A}^{2}\right.$ and $\left.\sigma_{D}^{2}\right)$ were calculated by taking inbreeding coefficient $(F)$ equal to one; that is, $F=1$ because both lines and testers were inbred.

Significance test for general combining ability and specific combining ability effects were performed using $t$-test. Mid-parent heterosis $\left(H_{\mathrm{PM}}\right)$ is defined as the increased vigor of the $F_{1}$ over the mean of the parents. It was estimated from mean values and its significance was performed using $t$-test [21]. Narrow sense heritability was estimated, after derivation of the variance components [20]. $\left(\sigma_{\mathrm{gca}}^{2} / \sigma_{\text {sca }}^{2}\right)$, and $\left(\sigma_{D}^{2} / \sigma_{A}^{2}\right)^{1 / 2}$ ratios were used to rate the relative weight of additive versus nonadditive type of gene actions [22].

\section{Results and Discussion}

3.1. Genetic Variability among Parents and Hybrids. The analysis of variance revealed significant genotype effect for all the characters under study. This provides evidence of the presence of sufficient genetic variability among lines, testers, and hybrids and allows further assessment of general combining ability analysis (Table 2). Differences between the extreme mean values for the measured traits were 8.7 days, $36.6 \mathrm{~cm}, 3.4 \mathrm{~cm}, 10.4$ tillers, $15.3 \mathrm{~g}, 33.7$ grains, and $16.1 \mathrm{~g}$ for days to heading, plant height, spike length, fertile tillers, 1000kernel weight, grains per spike, and grain yield, respectively. These differences were 3 to 5 times higher than the LSD0.05 values. Parents and crosses showed significant effects for all traits. Mean square of the contrast "parents versus crosses" was significant for days to heading, plant height, spike length, fertile tillers, and grain yield and nonsignificant for 1000kernel weight and number of grains per spike (Table 2). The differences between overall mean of parents and that of hybrids indicated that hybrids were 1.1 days earlier, $4.0 \mathrm{~cm}$ taller and had more effective tillers and a grain yield advantage of $2.7 \mathrm{~g}$. Parents and hybrids showed similar averages for 1000-kernel weight and number of grains per spike (Table 3). Line and tester effects were significant for all traits (Table 2).

Among lines, the differences, between the extreme mean values for the measured traits, were 5.4 days, $14.7 \mathrm{~cm}, 2.5 \mathrm{~cm}$, 7.2 tillers, $8.9 \mathrm{~g}, 15.6$ grains, and $11.2 \mathrm{~g}$ for days to heading, plant height, spike length, fertile tillers, 1000-kernel weight, grains per spike, and grain yield, respectively (Table 3 ). The best grain yielding line is $\mathrm{A}_{1135}$ which is the tallest and had also the highest average for the number of fertile tillers and 1000-kernel weight (Table 3). $\mathrm{A}_{1069}$ was the earliest with an average of 132.3 days, while Ain Abid (AA) had the longest and most fertile spike (Table 3). Among testers, the differences, between the extreme mean values for the characters under study, were 7.3 days, $36.6 \mathrm{~cm}, 2.2 \mathrm{~cm}, 8.4$ tillers, $11.9 \mathrm{~g}, 28.7$ grains, and $6.9 \mathrm{~g}$ for days to heading, plant height, spike length, fertile tillers, 1000-kernel weight, grains per spike, and grain yield, respectively (Table 3 ). The best grain yielding tester was Rmada (20.4 g) which exhibited also the longest spike $(13.6 \mathrm{~cm})$. Wifak was the earliest with an average of 132.7 days, while Mahon Demias (MD) was the tallest with $99.8 \mathrm{~cm}$ and presented the highest mean for the number of fertile tillers and 1000-kernel weight. $\mathrm{HD}_{1220}$ expressed the best average of the number of grains per spike (Table 3). Compared to testers, lines showed shorter plant height $(-5.1 \mathrm{~cm})$, lighter 1000-kernel weight $(-2.6 \mathrm{~g})$, and higher number of grains per spike (+6.3 grains). The interaction lines $\times$ testers were significant for plant height, spike length, fertile tillers, number of grains per spike, and 
TABLE 3: Means of the measured characters for 9 bread wheat parents and their $20 \mathrm{~F}_{1}$ hybrids.

\begin{tabular}{|c|c|c|c|c|c|c|c|}
\hline & DHE & PHT & SL & FT & TKW & NG & GY \\
\hline \multicolumn{8}{|l|}{ Lines } \\
\hline$A_{901}$ & $133.0^{\text {efg }}$ & $66.2^{\mathrm{jk}}$ & $11.8^{\mathrm{hij}}$ & $7.8^{\mathrm{h}}$ & $23.9^{\mathrm{i}}$ & $55.1^{\mathrm{ab}}$ & $10.5^{\mathrm{i}}$ \\
\hline $\mathrm{A}_{899}$ & $137.3^{\mathrm{b}}$ & $69.6^{\text {hijk }}$ & $11.5^{\mathrm{ij}}$ & $13.7^{\text {abcdef }}$ & $32.7^{\text {abcdefgh }}$ & $44.9^{\text {cdef }}$ & $20.0^{\mathrm{abcdefgh}}$ \\
\hline $\mathrm{A}_{1135}$ & $132.7^{\mathrm{efg}}$ & $80.9^{\text {bcdef }}$ & $13.5^{\text {abcde }}$ & $15.0^{\mathrm{abcd}}$ & $32.8^{\text {abcdefg }}$ & $44.4^{\mathrm{def}}$ & $21.7^{\text {abcdefg }}$ \\
\hline$A_{1069}$ & $132.3^{\text {efg }}$ & $73.1^{\text {efghij }}$ & $12.7^{\text {efghij }}$ & $11.8^{\text {bcdefgh }}$ & $32.4^{\text {abcdefgh }}$ & $49.9^{\text {bcdef }}$ & $18.8^{\text {abcdefgh }}$ \\
\hline AA & $137.7^{\mathrm{ab}}$ & $71.6^{\text {fghijk }}$ & $14.0^{\text {abcde }}$ & $8.8^{\text {efgh }}$ & $26.1^{\text {ghi }}$ & $60.0^{\mathrm{a}}$ & $13.7^{\text {ghi }}$ \\
\hline \multicolumn{8}{|l|}{ Testers } \\
\hline MD & $140.0^{\mathrm{a}}$ & $99.8^{\mathrm{a}}$ & $11.4^{j}$ & $16.8^{\mathrm{ab}}$ & $39.2^{\mathrm{a}}$ & $26.3^{\mathrm{h}}$ & $17.3^{\text {bcdefghi }}$ \\
\hline Rmada & $132.7^{\mathrm{efg}}$ & $76.0^{\text {efghi }}$ & $13.6^{\mathrm{abcde}}$ & $14.1^{\mathrm{abcd}}$ & $29.5^{\text {abcdefgh }}$ & $47.6^{\text {bcdef }}$ & $20.4^{\text {abcdefgh }}$ \\
\hline $\mathrm{HD}_{1220}$ & $137.3^{\mathrm{b}}$ & $63.2^{\mathrm{k}}$ & $12.2^{\text {fghij }}$ & $12.4^{\text {bcdefgh }}$ & $27.3^{\text {abcdefgh }}$ & $55.0^{\mathrm{ab}}$ & $18.8^{\text {abcdefgh }}$ \\
\hline Wifak & $132.7^{\mathrm{efg}}$ & $70.6^{\text {ghijk }}$ & $12.8^{\text {defghi }}$ & $8.4^{\mathrm{fgh}}$ & $32.8^{\mathrm{hi}}$ & $49.3^{\text {bcdef }}$ & $13.5^{\mathrm{hi}}$ \\
\hline \multicolumn{8}{|l|}{ Lines $\times$ testers } \\
\hline $\mathrm{A}_{901} \times \mathrm{MD}$ & $134.3^{\mathrm{def}}$ & $87.6^{b c}$ & $13.2^{\text {bcdefg }}$ & $14.7^{\mathrm{abcd}}$ & $32.1^{\text {cdef }}$ & $42.6^{\text {efg }}$ & $20.2^{\text {abcdefgh }}$ \\
\hline $\mathrm{A}_{901} \times \mathrm{Rmada}$ & $132.7^{\mathrm{efg}}$ & $75.2^{\text {fghij }}$ & $13.5^{\text {abcdef }}$ & $14.9^{\mathrm{abcd}}$ & $27.0^{\text {hij }}$ & $51.8^{\mathrm{abcd}}$ & $20.6^{\text {abcdefgh }}$ \\
\hline $\mathrm{A}_{901} \times \mathrm{HD}_{1220}$ & $134.7^{\text {cde }}$ & $69.8^{\text {hijk }}$ & $11.9^{\text {ghij }}$ & $10.9^{\text {cdefgh }}$ & $25.0^{\mathrm{j}}$ & $50.6^{\text {bcdef }}$ & $14.6^{\text {fghi }}$ \\
\hline $\mathrm{A}_{901} \times$ Wifak & $133.7^{\text {defg }}$ & $67.1^{\mathrm{ijk}}$ & $11.9^{\text {ghij }}$ & $8.3^{\mathrm{gh}}$ & $29.3^{\text {fghij }}$ & $60.0^{\mathrm{a}}$ & $15.4^{\text {efghi }}$ \\
\hline $\mathrm{A}_{899} \times \mathrm{MD}$ & $137.0^{\mathrm{bc}}$ & $89.6^{\mathrm{b}}$ & $13.1^{\text {cdefgh }}$ & $17.7^{\mathrm{a}}$ & $33.1^{\mathrm{bcde}}$ & $34.9^{\mathrm{gh}}$ & $20.4^{\text {abcdefgh }}$ \\
\hline $\mathrm{A}_{899} \times \mathrm{Rmada}$ & $132.0^{\mathrm{fg}}$ & $75.8^{\text {efghi }}$ & $14.1^{\mathrm{abcd}}$ & $16.5^{\mathrm{ab}}$ & $29.7^{\text {defghi }}$ & $49.3^{\text {bcdef }}$ & $24.2^{\mathrm{abc}}$ \\
\hline $\mathrm{A}_{899} \times \mathrm{HD}_{1220}$ & $135.7^{\mathrm{bcd}}$ & $70.6^{\text {ghijk }}$ & $11.8^{\text {ghij }}$ & $13.9^{\text {abcde }}$ & $29.4^{\text {efghi }}$ & $50.2^{\text {bcdef }}$ & $20.2^{\text {abcdefgh }}$ \\
\hline $\mathrm{A}_{899} \times$ Wifak & $132.3^{\text {efg }}$ & $78.0^{\text {cdefgh }}$ & $14.0^{\text {abcde }}$ & $18.2^{\mathrm{a}}$ & $29.5^{\text {efghi }}$ & $50.5^{\text {bcdef }}$ & $26.6^{\mathrm{a}}$ \\
\hline $\mathrm{A}_{1135} \times \mathrm{MD}$ & $138.0^{\mathrm{ab}}$ & $82.2^{\text {bcde }}$ & $11.6^{\mathrm{ij}}$ & $14.0^{\text {abcde }}$ & $35.2^{\mathrm{bc}}$ & $34.7^{\mathrm{gh}}$ & $17.3^{\text {bcdefghi }}$ \\
\hline $\mathrm{A}_{1135} \times \mathrm{Rmada}$ & $132.0^{\mathrm{fg}}$ & $80.3^{\text {bcdef }}$ & $14.1^{\mathrm{abc}}$ & $13.3^{\text {abcdefg }}$ & $30.7^{\text {defgh }}$ & $47.5^{\text {bcdef }}$ & $19.4^{\text {abcdefgh }}$ \\
\hline $\mathrm{A}_{1135} \times \mathrm{HD}_{1220}$ & $133.7^{\text {defg }}$ & $74.5^{\text {efghij }}$ & $14.0^{\text {abcde }}$ & $15.1^{\mathrm{abcd}}$ & $32.0^{\text {cdef }}$ & $47.8^{\text {bcdef }}$ & $22.7^{\text {abcde }}$ \\
\hline $\mathrm{A}_{1135} \times$ Wifak & $131.3^{\mathrm{g}}$ & $80.0^{\text {cdefg }}$ & $14.5^{\mathrm{ab}}$ & $16.1^{\mathrm{abc}}$ & $31.4^{\text {cdefg }}$ & $48.0^{\text {bcdef }}$ & $24.3^{\mathrm{ab}}$ \\
\hline $\mathrm{A}_{1069} \times \mathrm{MD}$ & $134.3^{\text {def }}$ & $99.2^{\mathrm{a}}$ & $13.3^{\text {bcdef }}$ & $15.1^{\mathrm{abcd}}$ & $36.8^{\mathrm{ab}}$ & $42.4^{\mathrm{fg}}$ & $23.6^{\mathrm{abcd}}$ \\
\hline $\mathrm{A}_{1069} \times \mathrm{Rmada}$ & $132.0^{\mathrm{fg}}$ & $77.7^{\text {defgh }}$ & $13.7^{\text {abcde }}$ & $13.9^{\text {abcde }}$ & $29.9^{\text {defghi }}$ & $53.7^{\mathrm{abc}}$ & $22.2^{\text {abcdef }}$ \\
\hline $\mathrm{A}_{1069} \times \mathrm{HD}_{1220}$ & $133.7^{\text {defg }}$ & $74.0^{\text {efghij }}$ & $13.4^{\text {bcdef }}$ & $12.1^{\text {bcdefgh }}$ & $29.0^{\text {fghi }}$ & $50.2^{\text {bcdef }}$ & $17.4^{\text {bcdefghi }}$ \\
\hline $\mathrm{A}_{1069} \times$ Wifak & $132.0^{\mathrm{fg}}$ & $78.4^{\text {cdefgh }}$ & $14.0^{\text {abcde }}$ & $13.7^{\mathrm{abcde}}$ & $30.3^{\text {defgh }}$ & $48.1^{\text {bcdef }}$ & $19.7^{\text {abcdefgh }}$ \\
\hline $\mathrm{AA} \times \mathrm{MD}$ & $135.7^{\mathrm{bcd}}$ & $86.1^{\mathrm{bcd}}$ & $13.8^{\text {abcde }}$ & $12.1^{\text {bcdefgh }}$ & $33.6^{\mathrm{bcd}}$ & $51.5^{\mathrm{abcdef}}$ & $20.0^{\text {abcdefgh }}$ \\
\hline AA $\times$ Rmada & $134.0^{\mathrm{def}}$ & $77.5^{\text {defgh }}$ & $14.8^{\mathrm{a}}$ & $10.5^{\text {defgh }}$ & $29.7^{\text {defghi }}$ & $52.2^{\mathrm{abcd}}$ & $16.2^{\text {cdefghi }}$ \\
\hline $\mathrm{AA} \times \mathrm{HD}_{1220}$ & $137.0^{\mathrm{bc}}$ & $71.7^{\text {fghijk }}$ & $13.9^{\text {abcde }}$ & $11.1^{\text {cdefgh }}$ & $27.8^{\text {ghij }}$ & $52.1^{\mathrm{abcd}}$ & $15.7^{\text {defghi }}$ \\
\hline AA $\times$ Wifak & $134.0^{\mathrm{def}}$ & $76.5^{\text {efghi }}$ & $13.6^{\text {abcde }}$ & $10.8^{\text {cdefgh }}$ & $30.1^{\text {defghi }}$ & $51.6^{\text {abcde }}$ & $16.6^{\text {bcdefghi }}$ \\
\hline Over all mean & 134.3 & 77.3 & 13.2 & 13.2 & 30.6 & 48.4 & 19.0 \\
\hline LSD0.05 & 1.9 & 6.9 & 1.0 & 2.2 & 2.9 & 6.6 & 3.0 \\
\hline
\end{tabular}

DHE: number of days to heading, PHT: plant height $(\mathrm{cm})$, SL: spike length $(\mathrm{cm})$, FT: number of fertile tillers, TKW: thousand-kernel weight (g), NG: number of grains per spike, and GY: grain yield (g).

Means within each column followed by the same letter are not significantly different from each other based on the 0.05 probability level of LSD.

grain yield, suggesting that hybrids perform better than the parents for these traits (Table 2).

Mean values of the hybrids were within the limits of the means of the parents for the number of days to heading, plant height, spike length, and number of grain per spike. For grain yield, $\mathrm{A}_{899} \times \mathrm{Rmada}, \mathrm{A}_{899} \times$ Wifak and $\mathrm{A}_{1135} \times$ Wifak cross-combinations presented higher mean values than the parents (Table 3). Genetic variability and mean performance of parents and hybrids are important criteria for genotypic evaluation; however, the parents with high mean value may not transmit this characteristic to their hybrids. These parental and hybrid abilities are estimated in terms of general combining ability (GCA) and specific combining ability (SCA) effects.
3.2. General and Specific Combining Ability Effects. The significance of mean squares, due to lines and testers, for the number of days to heading and 1000-kernel weight suggested the prevalence of additive genetic effects for these traits. While the simultaneous significance of mean squares due to lines, testers and lines $\times$ testers for plant height, spike length, fertile tillers, number of grains per spike and grain yield indicated that both additive and nonadditive type of gene action were involved in the genetic control of these characters. $\mathrm{A}_{901}, \mathrm{~A}_{899}$, and $\mathrm{AA}$ lines and the tester $\mathrm{HD}_{1220}$ exhibited significant but negative GCA for grain yield. $A_{901}$ line and the tester Wifak presented significant and positive GCA effects for the number of grains per spike (Table 4). $\mathrm{MD}$ is the best combiner for 1000-kernel weight, number 
TABLE 4: General combining ability (gi) effects for characters in bread wheat parents.

\begin{tabular}{|c|c|c|c|c|c|c|c|}
\hline Parents & DHE & PHT & SL & FT & TKW & NG & GY \\
\hline \multicolumn{8}{|l|}{ Lines } \\
\hline $\mathrm{A}_{901}$ & -0.25 & $-5.53^{* *}$ & $-1.20^{* *}$ & $-2.17^{*}$ & $-3.34^{* *}$ & $4.17^{* *}$ & $-3.26^{*}$ \\
\hline $\mathrm{A}_{899}$ & 0.38 & -0.12 & -0.23 & $4.41^{* *}$ & -0.23 & $-3.41^{*}$ & $-4.47^{* *}$ \\
\hline $\mathrm{A}_{1135}$ & -0.38 & 1 & 0.2 & 1.47 & $2.64^{* *}$ & $-5.98^{* *}$ & 1.61 \\
\hline $\mathrm{A}_{1069}$ & $-1.50^{* *}$ & $5.64^{* *}$ & 0.28 & 0.09 & $1.34^{*}$ & 0.16 & 1.28 \\
\hline $\mathrm{AA}$ & $1.75^{* *}$ & -0.99 & $0.95^{* *}$ & $-3.80^{* *}$ & -0.4 & $5.05^{* *}$ & $-4.11^{* *}$ \\
\hline $\operatorname{se}\left(g_{l}\right)$ & 0.45 & 1.64 & 0.23 & 0.9 & 0.61 & 0.45 & 1.35 \\
\hline \multicolumn{8}{|l|}{ Testers } \\
\hline $\mathrm{MD}$ & $2.80^{* *}$ & $15.52^{* *}$ & $-0.61^{* *}$ & $1.64^{*}$ & $5.38^{* *}$ & $-10.9^{* *}$ & 0.63 \\
\hline Rmada & $-2.20^{* *}$ & -1.92 & $0.96^{* *}$ & 0.27 & $-1.76^{* *}$ & $3.6^{* *}$ & 0.97 \\
\hline $\mathrm{HD}_{1220}$ & $1.40^{* *}$ & $-9.74^{* *}$ & $-0.63^{* *}$ & $-1.58^{*}$ & $-2.92^{* *}$ & 2.55 & $-2.58^{*}$ \\
\hline Wifak & $-2.00^{* *}$ & $-3.86^{* *}$ & 0.28 & -0.33 & -0.71 & $4.7^{* *}$ & 0.98 \\
\hline $\operatorname{se}\left(g_{t}\right)$ & 0.39 & 1.42 & 0.2 & 0.78 & 0.53 & 1.29 & 1.17 \\
\hline
\end{tabular}

DHE: number of days to heading, PHT: plant height $(\mathrm{cm})$, SL: spike length $(\mathrm{cm})$, FT: number of fertile tillers, TKW: thousand-kernel weight (g), NG: number of grains per spike, GY: grain yield $(\mathrm{g})$, se $\left(g_{l}\right)$ : standard error for GCA effects for line, se $\left(g_{t}\right)$ : standard error for GCA effects for tester, ns, and $*$ and $* *$ : nonsignificant and significant effect at 0.05 and 0.01 probability.

of fertile tillers, and the number of days to heading, with GCA effect of $5.38,1.64$, and 2.80 , respectively. $\mathrm{HD}_{1220}$ is a good general combiner to reduce plant height (Table 4). Significant negative GCA effect for plant height is useful for the development of dwarf plant material. The tester Rmada had significant and negative GCA for the number of days to heading. This tester is a good general combiner to shorten the duration of the vegetative growth period.

Even though SCA effects do not contribute tangibly in the improvement of self-pollinated crops, except in situations where exploitation of heterosis is feasible, best hybrids are expected to generate transgressive segregants which could be selected as potent homozygous lines. $\mathrm{A}_{901} \times \mathrm{MD}$ hybrid exhibited significant SCA effects, simultaneously, for the number days to heading and spike length. This crosscombination is best suited to select among its offspring's the earliest ones, bearing long spike (Table 5). According to Kenga et al. [23], cross-combinations with high means, favorable SCA estimates and involving at least one of the parents with high GCA would likely enhance the concentration of favorable alleles to improve target traits. In the present study, it is worth noting that $\mathrm{A}_{901}$ presented a significant and negative GCA effect for spike length while MD presented significant GCA, negative for spike length and positive for days to heading (Table 4). The positive SCA effect for spike length of this cross-combination resulted from parents having both significant and negative GCA. One parent of this hybrid presented a positive and significant GCA for days to heading while the hybrid exhibited a significant and negative SCA for this trait (Tables 4 and 5). $A_{901} \times$ Rmada presented a significant and positive SCA effect for the number of fertile tillers per plant. One parent of this cross-combination, the line $A_{901}$, had a significant and negative GCA for the number of fertile tillers. $A_{901} \times$ Wifak exhibited significant SCA effects, negative for plant height, spike length, fertile tillers, and positive for 1000-kernel weight and number of grains per spike (Table 5). Both parents, $A_{901}$ and Wifak, of this cross presented significant GCA for the number of grains per spike and plant height; and at least one parent had significant GCA effect for days to heading (Wifak), spike length, and the number of fertile tillers $\left(A_{901}\right)$ (Table 4). This hybrid is a best specific combiner to reduce plant height and to increase 1000 -kernel weight and number of grains per spike. However this cross-combination presents the disadvantage to reduce the number of fertile tillers, which is a strong determinant of grain yield, under semiarid growth conditions [24].

$\mathrm{A}_{1069} \times \mathrm{MD}$ cross-combination has significant and positive SCA for plant height and 1000-kernel weight. This cross is a best specific combiner to increase plant height and 1000-kernel weight. AA $\times$ MD presented significant and negative SCA effect for days to heading and plant height and significant and positive SCA effect for the number of kernels per spike. This cross is a best specific combiner to reduce duration of the vegetative period, plant height and to increase the number of kernels per spike (Table 5). None of the hybrids exhibited significant SCA effect for grain yield, suggesting even though the parents varied widely for grain yield, they generated hybrids with grain yield averages within the grain yield limits of the parents.

3.3. Gene Action, Degree of Dominance, Heterosis, Heritability, and Contribution to the Total Variance. The variance due to general combining ability $\left(\sigma_{\text {gca }}^{2}\right)$ was lower than specific combining ability variance $\left(\sigma_{\mathrm{sca}}^{2}\right)$ for all traits studied, suggesting the preponderance of nonadditive gene action controlling these characters (Table 6). Dominance genetic variance was larger than additive genetic variance for all traits. These results are supported by ratio of variance of general to specific combining ability $\left(\sigma_{\mathrm{gca}}^{2} / \sigma_{\mathrm{sca}}^{2}\right)$ which was smaller than unity and by the degree of dominance $\left(\sigma_{D}^{2} / \sigma_{A}^{2}\right)^{1 / 2}$ which takes values greater than unity (Table 6). Therefore, it appeared that the inheritance of all the studied characters was controlled by a preponderance of nonadditive gene effects. Such type 
TABLE 5: Specific combining ability (sij) effects for characters in bread wheat hybrids.

\begin{tabular}{|c|c|c|c|c|c|c|c|}
\hline Crosses & DHE & PHT & SL & FT & TKW & NG & GY \\
\hline $\mathrm{A}_{901} \times \mathrm{MD}$ & $-2.05^{*}$ & 3.5 & $1.44^{* *}$ & 2.17 & 0.32 & -2.05 & 3.1 \\
\hline $\mathrm{A}_{901} \times \mathrm{Rmada}$ & 0.45 & 2.32 & 0.36 & $3.74^{*}$ & -0.33 & -2.81 & 3.39 \\
\hline $\mathrm{A}_{901} \times \mathrm{HD}_{1220}$ & -0.15 & 2.07 & -0.49 & -0.41 & $-2.14^{*}$ & -3.51 & -2 \\
\hline $\mathrm{A}_{901} \times$ Wifak & 1.75 & $-7.89^{* *}$ & $-1.31^{* *}$ & $-5.50^{* *}$ & $2.14^{*}$ & $8.36^{* *}$ & -4.5 \\
\hline $\mathrm{A}_{899} \times \mathrm{MD}$ & 1.32 & 1.15 & 0.41 & 0.09 & -1.33 & $-6.11^{*}$ & -4.31 \\
\hline $\mathrm{A}_{899} \times \mathrm{Rmada}$ & -1.17 & -2.14 & 0.31 & -0.34 & 0.74 & 0.94 & 1 \\
\hline $\mathrm{A}_{899} \times \mathrm{HD}_{1220}$ & 0.72 & -2.17 & $-1.50^{* *}$ & -2.5 & 1.32 & 3.5 & -1.35 \\
\hline $\mathrm{A}_{899} \times$ Wifak & -0.87 & 3.17 & 0.77 & 2.76 & -0.74 & 1.68 & 4.67 \\
\hline $\mathrm{A}_{1135} \times \mathrm{MD}$ & $3.57^{* *}$ & $-11.14^{* *}$ & $-2.30^{* *}$ & -2.57 & -1.11 & -3.84 & 3.7 \\
\hline $\mathrm{A}_{1135} \times$ Rmada & -0.42 & 3.56 & -0.06 & -2.2 & -0.64 & 0.9 & 1.22 \\
\hline $\mathrm{A}_{1135} \times \mathrm{HD}_{1220}$ & -1.52 & 2.58 & -1.26 & 2.26 & 2.44 & 2.39 & -2.43 \\
\hline $\mathrm{A}_{1135} \times$ Wifak & -1.62 & 5 & -1.11 & 2.5 & -0.69 & 0.55 & -2.49 \\
\hline $\mathrm{A}_{1069} \times \mathrm{MD}$ & -0.8 & $9.79^{* *}$ & 0.23 & 0.52 & $2.56^{*}$ & 1.59 & 6.1 \\
\hline $\mathrm{A}_{1069} \times \mathrm{Rmada}$ & 0.7 & -4.97 & $-0.82^{*}$ & -0.02 & -0.65 & 4.04 & 1.37 \\
\hline $\mathrm{A}_{1069} \times \mathrm{HD}_{1220}$ & -0.4 & -2.81 & 0.29 & -0.87 & -0.8 & -0.16 & -3.83 \\
\hline $\mathrm{A}_{1069} \times$ Wifak & 0.5 & -2.01 & 0.29 & 0.38 & -1.11 & $-5.47^{*}$ & -3.64 \\
\hline $\mathrm{AA} \times \mathrm{MD}$ & $-2.05^{*}$ & $-3.30^{* *}$ & 0.22 & -0.2 & -0.45 & $10.41^{* *}$ & 3.62 \\
\hline $\mathrm{AA} \times \mathrm{Rmada}$ & 0.45 & 1.23 & 0.2 & -1.18 & 0.88 & -3.08 & -2.3 \\
\hline $\mathrm{AA} \times \mathrm{HD}_{1220}$ & 1.35 & 0.34 & 0.44 & 1.52 & -0.82 & -2.21 & 0.49 \\
\hline AA $\times$ Wifak & 0.25 & 1.73 & $-0.86^{*}$ & -0.13 & 0.39 & -5.12 & -1.8 \\
\hline Se (sij) & 0.77 & 2.84 & 0.39 & 2.84 & 1.06 & 2.58 & 2.34 \\
\hline
\end{tabular}

DHE: number of days to heading, PHT: plant height (cm), SL: spike length $(\mathrm{cm})$, FT: number of fertile tillers, TKW: thousand-kernel weight (g), NG: number of grains per spike, GY: grain yield (g), se (sij): standard error for SCA effects for crosses, ns, and $*$ and $* *$ : non-significant and significant effect at 0.05 and 0.01 probability.

TABLE 6: Estimates of genetic components for the measured characters in bread wheat.

\begin{tabular}{|c|c|c|c|c|c|c|c|}
\hline & DHE & PHT & SL & FT & TKW & NG & GY \\
\hline$\overline{\sigma_{\mathrm{gca}}^{2}}$ & 1.93 & 27.65 & 0.07 & 1.68 & 4.10 & 14.69 & 1.49 \\
\hline$\sigma_{\mathrm{sca}}^{2}$ & 12.17 & 173.48 & 0.84 & 12.27 & 23.80 & 98.03 & 15.28 \\
\hline$\sigma_{A}^{2}$ & 3.87 & 55.30 & 0.15 & 3.36 & 8.20 & 29.38 & 2.97 \\
\hline$\sigma_{D}^{2}$ & 12.17 & 173.48 & 0.84 & 12.27 & 23.80 & 98.03 & 15.28 \\
\hline$\sigma_{\mathrm{gca}}^{2} / \sigma_{\mathrm{sca}}^{2}$ & 0.16 & 0.16 & 0.09 & 0.14 & 0.17 & 0.15 & 0.10 \\
\hline$\left[\sigma_{D}^{2} / \sigma_{A}^{2}\right]^{1 / 2}$ & 1.77 & 1.77 & 2.39 & 1.91 & 1.70 & 1.83 & 2.27 \\
\hline$h_{\mathrm{ns}}^{2}$ & 56.30 & 60.30 & 10.30 & 33.30 & 54.40 & 50.40 & 16.90 \\
\hline
\end{tabular}

$\sigma_{A}^{2}$ : additive genetic variance, $\sigma_{D}^{2}$ : dominance genetic variance, $h_{\mathrm{ns}}^{2}$ : narrow sense heritability, $\sigma_{\mathrm{gca}}^{2}$ : estimate of GCA variance, $\sigma_{\mathrm{sca}}^{2}$ : estimate of SCA variance, and $\sigma_{\mathrm{gca}}^{2} / \sigma_{\mathrm{sca}}^{2}$ : average degree of dominance. DHE: number of days to heading, PHT: plant height $(\mathrm{cm})$, SL: spike length $(\mathrm{cm})$, FT: number of fertile tillers, TKW: thousand-kernel weight (g), NG: number of grains per spike, and GY: grain yield (g).

of gene action clearly indicated that selection of superior plants, in terms of grain yield, plant height, fertile tillers, and duration of the vegetative growth period should be postponed to later generation, where these traits can be improved by making selections among the recombinants within the segregating populations.

Selection efficiency is related to the magnitude of heritability. In this study, low estimates of narrow-sense heritability were observed for grain yield and spike length, intermediate for the number of fertile tillers per plant, and high for the number of days to heading, plant height, 1000kernel weight, and number of grains per spike (Table 6).
Heterosis is the process by which the performance of an $F_{1}$ is superior to that of the mean of the crossed parents. Nine hybrids among 20 exhibited a significant mid-parent heterosis for grain yield. Besides, heterosis for grain yield, $A_{901} \times$ $\mathrm{MD}$, and $\mathrm{A}_{899} \times$ Rmada expressed significant heterosis for the number of fertile tillers, spike length and the number of days to heading (Table 7). $\mathrm{A}_{899} \times$ Wifak presented the highest heterosis for grain yield, accompanied with positive heterosis for the number of fertile tillers and spike length and negative heterosis for 1000-kernel weight and the number of days to heading (Table 7). Besides heterosis for grain yield, AA $\times$ MD hybrid exhibited significant and positive heterosis for 
TABLE 7: Significant mid-parent heterosis (\%) for seven traits in bread wheat genotypes.

\begin{tabular}{|c|c|c|c|c|c|c|c|}
\hline Crosses & DHE & PHT & SL & FT & TKW & NG & GY \\
\hline $\mathrm{A}_{901} \times \mathrm{MD}$ & -1.6 & & 13.8 & 19.5 & & & 45.3 \\
\hline $\mathrm{A}_{901} \times \mathrm{Rmada}$ & & & & 36.1 & & & 33.3 \\
\hline \multicolumn{8}{|l|}{$\mathrm{A}_{901} \times \mathrm{HD}_{1220}$} \\
\hline $\mathrm{A}_{901} \times$ Wifak & & & & & & 14.9 & 28.3 \\
\hline $\mathrm{A}_{899} \times \mathrm{MD}$ & & & 14.4 & 16.1 & & & \\
\hline $\mathrm{A}_{899} \times \mathrm{Rmada}$ & -2.2 & & 12.4 & 18.7 & & & 19.8 \\
\hline \multicolumn{8}{|l|}{$\mathrm{A}_{899} \times \mathrm{HD}_{1220}$} \\
\hline $\mathrm{A}_{899} \times$ Wifak & -2.0 & 11.3 & 15.2 & 64.7 & -9.9 & & 58.8 \\
\hline $\mathrm{A}_{1135} \times \mathrm{MD}$ & & -9.0 & & & & & \\
\hline \multicolumn{8}{|l|}{$\mathrm{A}_{1135} \times$ Rmada } \\
\hline \multicolumn{8}{|l|}{$\mathrm{A}_{1135} \times \mathrm{HD}_{1220}$} \\
\hline $\mathrm{A}_{1135} \times$ Wifak & & & 10.3 & 37.6 & & & 38.1 \\
\hline $\mathrm{A}_{1069} \times \mathrm{MD}$ & & 14.7 & 10.4 & & & 11.3 & 30.7 \\
\hline $\mathrm{A}_{1069} \times \mathrm{Rmada}$ & & & & & & 10.2 & \\
\hline \multicolumn{8}{|l|}{$\mathrm{A}_{1069} \times \mathrm{HD}_{1220}$} \\
\hline $\mathrm{A}_{1069} \times$ Wifak & & & 9.8 & 35.6 & & & 22.0 \\
\hline $\mathrm{AA} \times \mathrm{MD}$ & -2.3 & & 8.7 & & & 19.4 & 29.0 \\
\hline \multicolumn{8}{|l|}{$\mathrm{AA} \times$ Rmada } \\
\hline $\mathrm{AA} \times \mathrm{HD}_{1220}$ & & & & & & -9.4 & \\
\hline AA $\times$ Wifak & & & & & & & \\
\hline
\end{tabular}

DHE: number of days to heading, PHT: plant height $(\mathrm{cm})$, SL: spike length $(\mathrm{cm}), \mathrm{FT}$ : number of fertile tillers, TKW: thousand-kernel weight (g), NG: number of grains per spike, and GY: grain yield $(\mathrm{g})$.

TABLE 8: Proportional (\%) contribution of lines, testers, and lines $\times$ testers to total hybrids variation in bread wheat.

\begin{tabular}{lccccccc}
\hline & DHE & PHT & SL & FT & TKW & NG \\
\hline Lines (L) & 33.43 & 11.23 & 30.34 & 32.67 & 25.30 & 23.58 & 40.80 \\
Testers (T) & 46.71 & 71.06 & 17.24 & 32.44 & 64.50 & 52.49 & 12.05 \\
$\mathrm{~L} \times \mathrm{T}$ & 19.87 & 17.71 & 52.41 & 34.88 & 10.20 & 23.95 \\
\hline
\end{tabular}

DHE: number of days to heading, PHT: plant height (cm), SL: spike length $(\mathrm{cm})$, FT: number of fertile tillers, TKW: thousand-kernel weight (g), NG: number of grains per spike, and GY: grain yield $(\mathrm{g})$.

the number of grains per spike, spike length, and negative heterosis for the number of days to heading (Table 7). $\mathrm{A}_{1069} \times$ MD hybrid exhibited significant and positive heterosis for the number of grains per spike, spike length, and plant height (Table 7).

Testers contributed more to the total sum square for number of days to heading, plant height, thousand kernel weight, and number of grains per spike. The contribution of lines was lower compared to the testers and lines $\times$ testers interaction for all traits under study. All three sources of variation contributed equally for the number of fertile tillers per plant. Contribution of line $\times$ tester was slightly greater than that of testers and lines for grain yield and spike length (Table 8). These results showed that testers and the interaction lines $\times$ testers brought much variation in the expression of the studied traits. The results of the present study revealed large variation between parents and hybrids for the seven traits under study. Compared to the parents, hybrids were earlier, taller, bearing more effective tillers, and had higher grain yielding. $\mathrm{A}_{1135}$ line and Rmada tester were high grain yielding. Compared to testers, lines were shorter and had low 1000-kernel weight and higher number of grains per spike. Mean values of the hybrids were within the limits of the parental means for the number of days to heading, plant height, spike length, and number of grain per spike. $\mathrm{A}_{899} \times \mathrm{Rmada}$, $\mathrm{A}_{899} \times$ Wifak, and $\mathrm{A}_{1135} \times$ Wifak cross-combinations exhibited higher mean values for grain yield than the parents.

Concomitant significance of mean squares due to lines, testers, and lines $\times$ testers for plant height, spike length, fertile tillers, number of grains per spike, and grain yield suggested that both additive and nonadditive types of gene actions were involved in the genetic control of the characters. $A_{901}$ line and the tester Wifak were good combiners for the number of grains per spike. MD is a good combiner for 1000-kernel weight and number of fertile tillers. $\mathrm{HD}_{1220}$ is a good general combiner to reduce plant height, while the tester Rmada is a good general combiner to shorten the duration of the vegetative growth period.

$\mathrm{A}_{901} \times \mathrm{MD}$ hybrid exhibited significant SCA effects, simultaneously, for the number of days to heading and spike length. This cross-combination is best suited and offers the opportunity to select, among the progenies, early plant 
with long spike. This cross-combination resulted from $\mathrm{L} \times \mathrm{L}$ parents for spike length and $\mathrm{H} \times \mathrm{L}$ for days to heading. Verma and Srivastava [22] mentioned that positive SCA effect was usually associated with crosses where at least one parent was a good general combiner. According to Singh et al. [25] the desirable performance of combination like $\mathrm{H} \times \mathrm{L}$ may be ascribed to the interaction between dominant alleles from good combiners and recessive alleles from poor combiners. $\mathrm{A}_{901} \times$ Rmada presented a significant and positive SCA effect for the number of fertile tillers per plant. One parent of this cross-combination had significant and negative GCA for the number of fertile tillers. $A_{901} \times$ Wifak exhibited significant SCA effects, negative for plant height, spike length, fertile tillers, and positive for 1000-kernel weight and number of grains per spike. Both parents of this cross presented significant GCA for the number of grains per spike and plant height; and at least one parent had significant GCA effect for days to heading, spike length, and the number of fertile tillers. This hybrid is a best specific combiner to reduce plant height and to increase 1000-kernel weight and number of grains per spike. $A_{1069} \times M D$ cross-combination is a best specific combiner to increase plant height and 1000-kernel weight. $\mathrm{AA} \times \mathrm{MD}$ is a best specific combiner to reduce duration of the vegetative period, plant height and to increase the number of kernels per spike. None of the hybrids exhibited significant SCA effect for grain yield, suggesting even though the parents varied widely for grain yield, they generated hybrids with grain yield average within the grain yield limits of the parents. Tiwari et al. [26] mentioned that hybrid combinations, where at least one parent is a good general combiner, could be used to developing high yielding pure lines due to presence of additive gene action, even if these crosses showed nonsignificant SCA effects though. In this study $\mathrm{A}_{901}, \mathrm{~A}_{899}, \mathrm{AA}$, and $\mathrm{HD}_{1220}$ were poor general combiners for grain yield. $\sigma_{\text {gca }}^{2}$ was lower than $\sigma_{\text {sca }}^{2}$ and $\sigma_{D}^{2}$ was larger than $\sigma_{A}^{2}$ for all traits, suggesting the preponderance of nonadditive gene action. These results are supported by $\sigma_{\mathrm{gca}}^{2} / \sigma_{\mathrm{sca}}^{2}$ ratio which was smaller than unity and by $\left(\sigma_{D}^{2} / \sigma_{A}^{2}\right)^{1 / 2}$ ratio which takes values greater than unity. Premlatha et al. [27] reported the importance of nonadditive gene action for plant height and grain yield. Gnanasekaran et al. [28] reported nonadditive gene action for seed weight and plant height, while Sharma [29] reported an additive gene effect. Similar results of predominance of $\sigma_{\mathrm{sca}}^{2}$ variance over $\sigma_{\text {gca }}^{2}$ have been reported by Verma et al. [30] for barley. The results of this study do not corroborated findings reported by Borghi et al. [31] and Borghi and Perenzin [32] who observed that $\sigma_{\mathrm{gca}}^{2}$ was of greater importance than $\sigma_{\mathrm{sca}}^{2}$ for majority of characters. Lucken [33] noted that nonadditive $\sigma_{\text {sca }}^{2}$ is best expressed in space planting. The difference in the results of various pieces of research may be attributed to differences of breeding material and to genotype $\times$ environments. Betrán et al. [34] observed significant interactions for combining abilities under low and high nitrogen in maize. The preponderance of nonadditive type of gene actions clearly indicated that selection of superior plants, in terms of grain yield, plant height, fertile tillers, and duration of the vegetative growth period, should be postponed to later generation.
Low estimates of $h_{\mathrm{ns}}^{2}$ were observed for grain yield and spike length, intermediate for the number of fertile tillers per plant, and high for the number of days to heading, plant height, 1000-kernel weight, and number of grains per spike. This supported the involvement of both additive and nonadditive gene effects. Medium to high narrow sense heritability estimates were reported by Yadav et al. [35], for different traits. Nine hybrids among 20 exhibited a significant midparent heterosis for grain yield. Besides, heterosis for grain yield, $A_{901} \times M D$ and $A_{899} \times$ Rmada, expressed significant heterosis for the number of fertile tillers, spike length, and the number of days to heading. $A_{899} \times$ Wifak showed the highest heterosis for grain yield, accompanied with positive heterosis for the number of fertile tillers and spike length and negative heterosis for 1000-kernel weight and the number of days to heading. AA $\times$ MD hybrid exhibited significant and positive heterosis for the number of grains per spike, spike length, and negative heterosis for the number of days to heading. The results indicated that testers and the interaction lines $x$ testers contributed more to the variation in the expression of the studied traits.

\section{Conclusion}

$\mathrm{A}_{899} \times$ Rmada, $\mathrm{A}_{899} \times$ Wifak, and $\mathrm{A}_{1135} \times$ Wifak hybrids had greater grain yield mean than the parents. $\sigma_{\mathrm{gca}}^{2} / \sigma_{\mathrm{sca}}^{2}$, $\left(\sigma_{D}^{2} / \sigma_{A}^{2}\right)^{1 / 2}$ low ratios and low to intermediate estimates of $\mathrm{h}_{\mathrm{ns}}^{2}$ supported the involvement of both additive and nonadditive gene effects with preponderance of nonadditive type of gene actions. The testers and the interaction lines $\times$ testers contributed more to the variation of the expression of the different traits. $A_{901}$ line and the tester Wifak were good combiners for the number of grains per spike. MD is a good combiner for 1000-kernel weight and number of fertile tillers. $\mathrm{HD}_{1220}$ is a good general combiner to reduce plant height; Rmada is a good general combiner to shorten the duration of the vegetative growth period. $A_{901} \times$ Wifak is a best specific combiner to reduce plant height, to increase 1000-kernel weight and number of grains per spike. AA $\times$ $\mathrm{MD}$ is a best specific combiner to reduce duration of the vegetative period, plant height and to increase the number of kernels per spike. $A_{899} \times$ Wifak showed the highest heterosis for grain yield, accompanied with positive heterosis for the number of fertile tillers and spike length and negative heterosis for 1000-kernel weight and the number of days to heading. The preponderance of nonadditive type of gene actions clearly indicated that selection of superior plants should be postponed to later generations.

\section{References}

[1] O. Kempthorne, An Introduction to Genetic Statistics, John Wiley \& Sons, New York, NY, USA, 1957.

[2] M. Rashid, A. A. Cheema, and M. Ashraf, "Line x tester analysis in basmati rice," Pakistan Journal of Botany, vol. 39, no. 6, pp. 2035-2042, 2007.

[3] S. Basbag, R. Ekinci, and O. Gencer, "Combining ability and heterosis for earliness characters in line $\mathrm{x}$ tester population of 
Gossypium hirsutum L," Hereditas, vol. 144, no. 5, pp. 185-190, 2007.

[4] S. K. Jain and E. V. D. Sastry, "Heterosis and combining ability for grain yield and its contributing traits in bread wheat (Triticum aestivum L.)," RRJAAS, vol. 1, pp. 17-22, 2012.

[5] B. Xiang and B. Li, "A new mixed analytical method for genetic analysis of diallel data," The Canadian Journal of Forest Research, vol. 31, no. 12, pp. 2252-2259, 2001.

[6] W. Yan and L. A. Hunt, "Biplot analysis of diallel data," Crop Science, vol. 42, no. 1, pp. 21-30, 2002.

[7] M. Iqbal, A. Navabi, D. F. Salmon et al., "Genetic analysis of flowering and maturity time in high latitude spring wheat: genetic analysis of earliness in spring wheat," Euphytica, vol. 154, no. 1-2, pp. 207-218, 2007.

[8] P. G. Swati and B. R. Ramesh, "The nature and divergence in relation to yield traits in rice germplasm," Annals of Agricultural Research, vol. 25, pp. 598-5602, 2004.

[9] Z. Hasnain, G. Abbas, A. Saeed, A. Shakeel, A. Muhammad, and M. A. Rahim, "Combining ability for plant height and yield related traits in wheat (Triticum aestivum L.)," Journal of Agricultural Research, vol. 44, pp. 167-1175, 2006.

[10] M. A. Chowdhary, M. Sajad, and M. I. Ashraf, "Analysis on combining ability of metric traits in bread wheat (Triticum aestivum L.)," Journal of Agricultural Research, vol. 45, pp. 11118, 2007.

[11] K. Kamaluddin, R. M. Singh, L. C. Prasad, M. Z. Abdin, and A. K. Joshi, "Combining ability analysis for grain filling duration and yield traits in spring wheat (Triticum aestivum L. Em. Thell)," Genetics and Molecular Biology, vol. 30, no. 2, pp. 411416, 2007.

[12] V. Kumar and S. R. Maloo, "Heterosis and combining ability studies for yield components and grain protein content in bread wheat (Triticum aestivum L.)," Indian Journal of Genetics and Plant Breeding, vol. 71, no. 4, pp. 363-366, 2011.

[13] N. Mahmood and M. A. Chowdhry, "Inheritance of flag leaf in bread wheat genotypes," Wheat Information Service, vol. 90, pp. 7-12, 2000.

[14] J. Ahmadi, A. A. Zali, B. Y. Samadi, A. Talaie, M. R. Ghannadha, and A. Saeidi, "A study of combining ability and gene effect in bread wheat under stress conditions by diallel method," Iranian Journal of Agricultural Sciences, vol. 34, pp. 1-18, 2003.

[15] M. A. Chowdhry, M. T. Mahmood, and I. Khaliq, "Genetic analysis of some drought and yield related characters in Pakistani spring wheat varieties," Wheat Information Service, vol. 82, pp. 11-118, 1996.

[16] F. Ahmad, S. Khan, A. Latif, H. Khan, A. Khan, and A. Nawaz, "Genetics of yield and related traits in bread wheat over different planting dates using diallel analysis," African Journal of Agricultural Research, vol. 6, no. 6, pp. 1564-1571, 2011.

[17] A. S. Khan and I. Habib, "Gene action in a five parent diallel cross of spring wheat (Triticum aestivum L.)," Pakistan Journal of Biological Sciences, vol. 6, pp. 1945-11948, 2003.

[18] L. Benderradji, F. Brini, S. B. Amar et al., "Sodium transport in the seedlings of two bread wheat (Triticum aestivum L.) Genotypes showing contrasting salt stress tolerance," Australian Journal of Crop Science, vol. 5, no. 3, pp. 233-241, 2011.

[19] R. G. D. Steel and J. H. Torrie, Principles and Procedures of Statistics: A Biometrical Approach, McGraw Hill, New York, NY, USA, 1980.

[20] R. K. Singh and B. D. Chaudhary, Biometrical Methods in Quantitative Genetic Analysis, Kalyani, New Delhi, India, 1985.
[21] G. Oettler, S. H. Tams, H. F. Utz, E. Bauer, and A. E. Melchinger, "Prospects for hybrid breeding in winter triticale: I. Heterosis and combining ability for agronomic traits in European elite germplasm," Crop Science, vol. 45, no. 4, pp. 1476-1482, 2005.

[22] O. P. Verma and H. K. Srivastava, "Genetic component and combining ability analyses in relation to heterosis for yield and associated traits using three diverse rice-growing ecosystems," Field Crops Research, vol. 88, no. 2-3, pp. 91-102, 2004.

[23] R. Kenga, S. O. Alabi, and S. C. Gupta, "Combining ability studies in tropical sorghum (Sorghum bicolor (L.) Moench)," Field Crops Research, vol. 88, no. 2-3, pp. 251-260, 2004.

[24] A. Adjabi, H. Bouzerzour, C. Lelarge, A. Benmahammed, A. Mekhlouf, and A. Hanachi, "Relationships between grain yield performance, temporal stability and carbon isotope discrimination in durum wheat (Triticum durum Desf.) under Mediterranean conditions," Journal of Agronomy, vol. 6, no. 2, pp. 294-301, 2007.

[25] N. B. Singh, V. P. Singh, and N. Singh, "Variation in physiological traits in promising wheat varieties under late sown condition," Indian Journal of Plant Physiology, vol. 19, pp. 171-175, 2005.

[26] D. K. Tiwari, P. Pandey, S. P. Giri, and J. L. Dwivedi, "Prediction of gene action, heterosis and combining ability to identify superior rice hybrids," International Journal of Botany, vol. 7, no. 2, pp. 126-144, 2011.

[27] M. Premlatha, A. Kalamani, and A. Nirmalakumari, "Heterosis and combining ability for grain yield and quality in maize (Zea mays L.)," Advances in Environmental Biology, vol. 5, no. 6, pp. 1264-1266, 2011.

[28] M. Gnanasekaran, P. Vivekanandan, and S. Muthuramu, "Combining ability and heterosis for yield and grain quality in two line rice (Oryza sativa L.) hybrids," Indian Journal of Human Genetics, vol. 66, pp. 6-69, 2006.

[29] R. K. Sharma, "Studies on gene action and combining ability for yield and its component traits in rice (Oryza sativa L.)," Indian Journal of Human Genetics, vol. 66, pp. 227-2228, 2006.

[30] A. K. Verma, S. R. Vishwakarma, and P. K. Singh, "Line x tester analysis in barley (Hordeum vulgare L.) across environments," Barley Genetics Newsletter, vol. 37, pp. 29-233, 2007.

[31] B. Borghi, M. Perenzin, and R. J. Nash, "Combining ability estimates in bread wheat and performances of 100 F1 hybrids produced using a chemical hybridizing agent," Journal of Genetics and Breeding, vol. 43, pp. 11-116, 1989.

[32] B. Borghi and M. Perenzin, "Diallel analysis to predict heterosis and combining ability for grain yield, yield components and bread-making quality in bread wheat (Triticum aestivum L.)," Theoretical and Applied Genetics, vol. 89, no. 7-8, pp. 975-981, 1994.

[33] K. A. Lucken, "The breeding and production of hybrid wheat, in USA genetic improvement in yield of wheat," in CSSA Spec. Pub. Crop Science Society of America and American Society of Agronomy, vol. 13, pp. 87-107, Madison, Wis, USA, 1986.

[34] F. J. Betrán, D. Beck, M. Bänziger, and G. O. Edmeades, “Genetic analysis of inbred and hybrid grain yield under stress and nonstress environments in tropical maize," Crop Science, vol. 43, no. 3, pp. 807-817, 2003.

[35] A. K. Yadav, R. K. Maan, S. Kumar, and P. Kumar, "Variability, heritability and genetic advance for quantitative characters in hexaploid wheat (Triticum aestivum L.)," Electronic Journal of Plant Breeding, vol. 2, pp. 405-4408, 2011. 


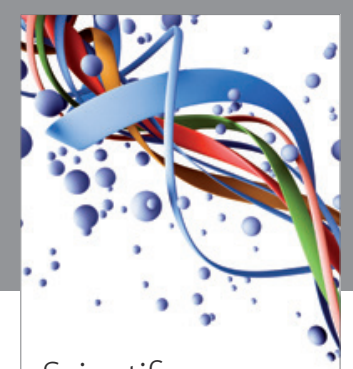

Scientifica
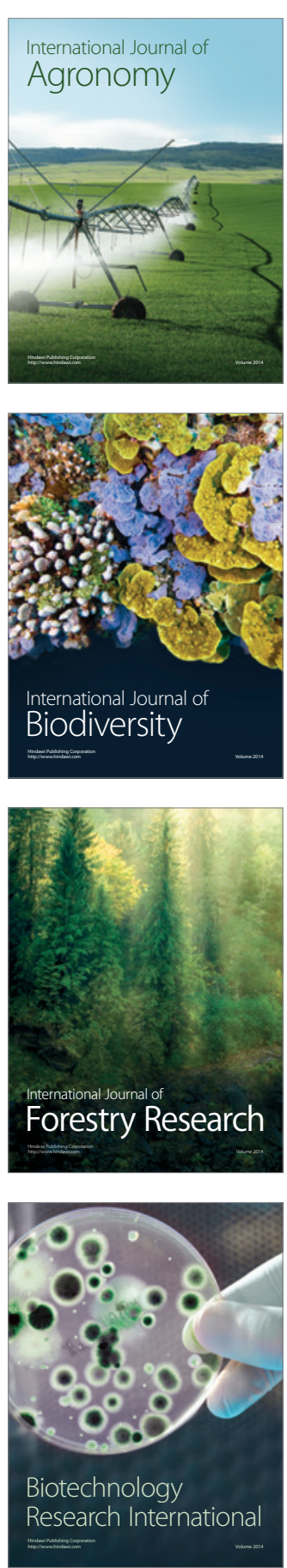
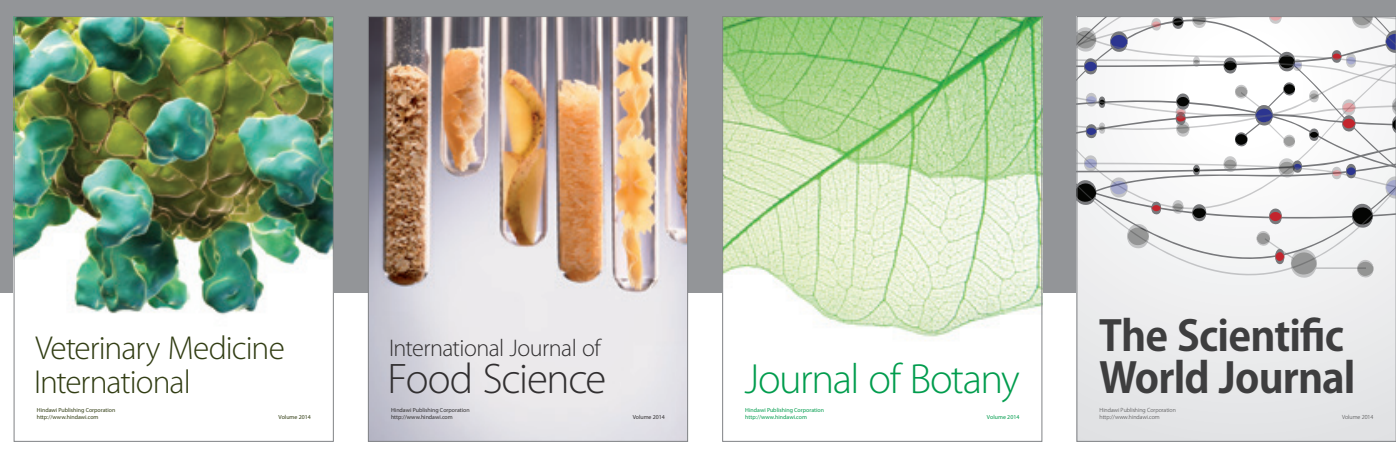

The Scientific World Journal
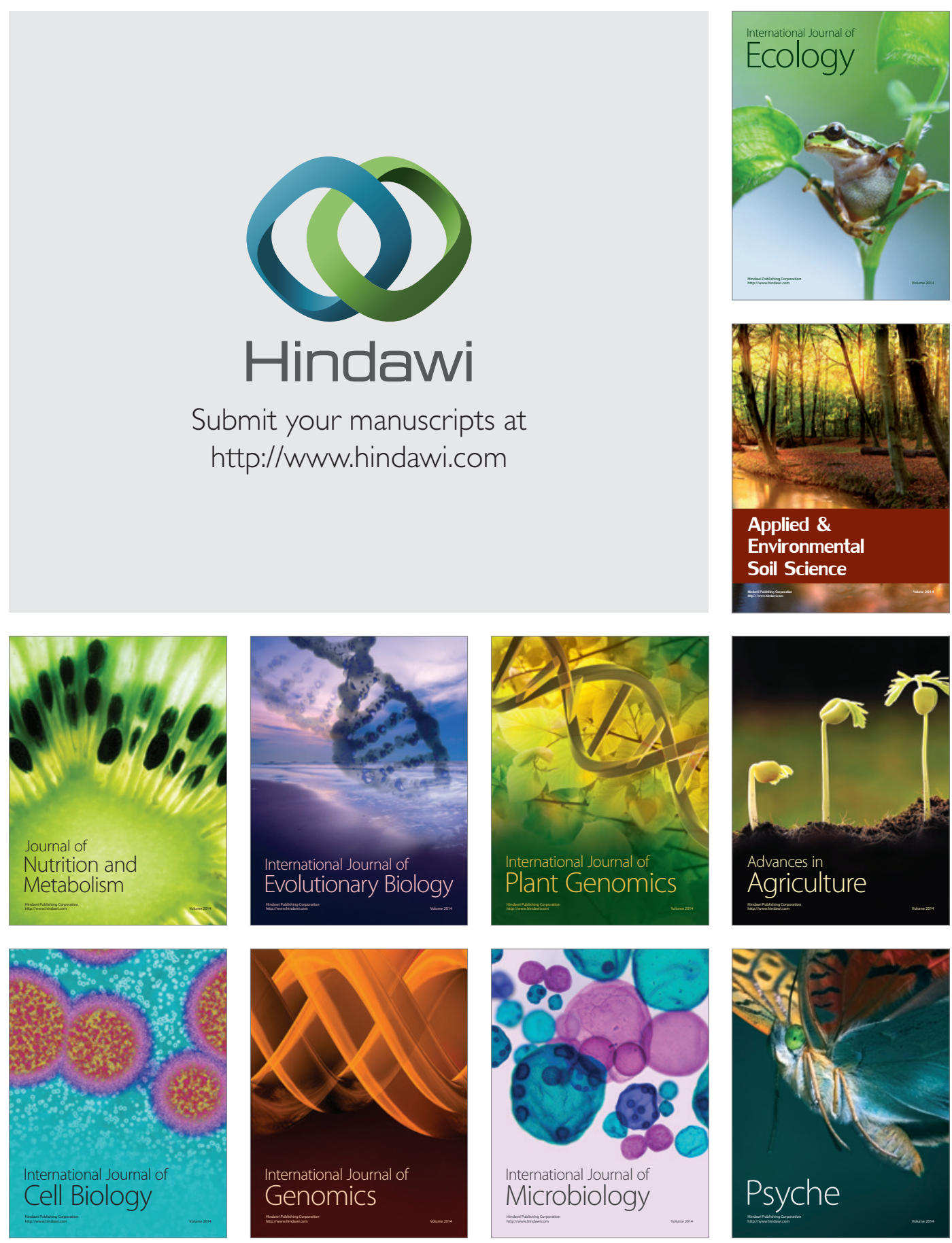